Article

\title{
The Influence of Compaction and Water Conditions on Shear Strength and Friction Resistance between Geotextiles and Ash-Slag Mixture
}

\author{
Andrzej Gruchot ${ }^{1, * \mathbb{D}}$, Tymoteusz Zydron ${ }^{1}$ (D) and Agata Michalska ${ }^{2}$ \\ 1 Department of Hydraulic Engineering and Geotechnics, University of Agriculture in Kraków, \\ al. Mickiewicza 24/28, 30-059 Kraków, Poland; tymoteusz.zydron@urk.edu.pl \\ 2 Arcadis Sp. z o.o., ul. Wadowicka 8A, 30-415 Kraków, Poland; agata.lubczynska@arcadis.com \\ * Correspondence: rmgrucho@cyf-kr.edu.pl; Tel.: +48-12-662-4136
}

Received: 9 January 2020; Accepted: 22 February 2020; Published: 1 March 2020

\begin{abstract}
The paper presents the results of tests of the shear strength of the ash-slag mixture taken from the landfill located in Kraków (Poland) and the interfacial friction resistance at the contact between the ash-slag mixture and woven or nonwoven geotextiles. The tests were carried out in a direct shear apparatus on samples with and without water saturation. The samples for testing were formed in the apparatus box at the optimum moisture by compacting them to $I_{S}=0.90$ and 1.00 . The test results reveal that the shear strength parameters of the ash-slag mixture were large. It was stated the significant influence of the compaction, the growth of which has resulted in an increase in the angle of internal friction (from $7 \%$ to $9 \%$ ) and cohesion (from $60 \%$ to $97 \%$ ). Whereas the saturation of the samples reduced the shear strength parameters (from $4 \%$ to $6 \%$, of the internal friction angle and $30 \%$ to $43 \%$ of cohesion). The values of the interfacial friction resistance at the contact between the ash-slag mixture and the geotextiles were large as well, but slightly smaller than the values of the shear strength parameters of the mixture itself. The compaction caused an increase in the angle of interfacial friction (from $1 \%$ to $5 \%$ ) and adhesion (from $31 \%$ to $127 \%$ ). The water-saturation of the samples caused a change in the angle of interfacial friction (from $-6 \%$ to $3 \%$ ) and decline in the adhesion (from $22 \%$ to $69 \%$ ). Values of the interaction coefficient were about $0.8-1.0$ and they tended to rise with increasing the normal stress. Higher values of this parameter were obtained in tests with water saturation and for non-woven geotextiles.
\end{abstract}

Keywords: ash-slag mixture; nonwoven and woven geotextile; shear strength; interfacial friction resistance

\section{Introduction}

In earth structures, more and more often, new types of material filling as well as strengthening embankments or retaining walls are being used. Structures of this type are usually made using reinforced soil technology, where a geogrid, a steel mesh or strips, as well as geosynthetics, can be the reinforcement. The use of strengthening requires research on the cooperation of the soil reinforcement system. Improperly selected reinforcement may weaken the shear strength of the soil and lead to a structural failure. The mechanism of interaction between the reinforcement and the surrounding soil has been determined by many researchers, most often in laboratory conditions (e.g., [1-4]). The phenomenon of interaction takes place in a thin layer of soil close to the reinforcement and depends on a number of complex phenomena in this layer [5-7], such as the physical properties of the soil (e.g., angularity of soil particles, relative density and degree of saturation) and geotextiles (e.g., roughness, hardness), as well as the testing conditions (e.g., testing method, dimensions of sample, boundary conditions) $[6,7]$. 
Another problem is the proper selection of a backfill material and its compaction. It is usually recommended to use materials with a high shear strength. As a filling, industrial wastes arising, for example, in the production of coal (coal shales), electricity or heat as a result of the coal combustion (ash slag mixtures, fly ash, slag, microsphere, ashes from the fluidized furnace) are also increasingly used. Wastes are generated in the combustion processes because there are large amounts of non-flammable substances, their content in coal ranges from $11 \%$ to $17 \%$ (hard coal extracted in Poland) and from $3 \%$ to $11 \%$ (lignite) [8]. The by-products of combustion can be used as artificial aggregates in earth structures [8-11]. The utilisation of these products in earth structures is of great importance from the economic and ecological points of view. The use of artificial aggregates and geosynthetics for strengthening the soil subgrade also has a significant impact on the protection of natural aggregates. It makes possible constructing the embankments of the selected industrial wastes and limits the scope of soil exchange.

In order to meet current requirements for earthworks, the use of geosynthetics that satisfy the requirements for acceleration and quality of works, as well as the optimization of costs of road pavement construction, have been started [12]. In addition to the versatility of using geosynthetics, their advantages include high material strength [13]. Currently, geosynthetics are the most commonly used materials to strengthen the subgrade and build road embankments, among others in reinforced soil technology [14-16]. The reinforcing function is visible in taking over external interactions, as well as in a favourable change in the distribution of stresses, arising in the subgrade and the body of the road [17]. Strengthening with the geosynthetic improves the mechanical properties of the soil due to the persisting tensile force, resulting in a reduction in shear forces, and thus increasing the shear strength of the soil [18]. The purpose of using soil reinforcement is to engage an interaction between the soil and the reinforcement in the plane of contact. This interaction occurs as a result of vertical stress from the weight of the soil that is on top of the reinforcement. Reinforcement with geosynthetics allows the soil to bear a greater load. In the case of embankments on a weak subgrade, burdened mainly with the dead load, reinforcement makes it possible to build them with steeper slopes.

The determination of the parameters of the mutual interaction between the soil and the geosynthetic is performed on the basis of tests in a direct shear apparatus, where the soil layer is moved along the geosynthetic or the geosynthetic is pulled out of two layers of soil ("pull-out test"). The research in the direct shear apparatus is used to describe the mechanisms of interaction between the geosynthetic and the material of the backfill, where the shear strength between the two materials is mobilized. The friction resistance of the geosynthetic interface can also be determined on the basis of tilt table device tests [19-21]. However, it should be pointed out that the direct shear apparatus tests are still the most popular method for testing geosynthetics (e.g., [7,22]). In this apparatus, there are also conducted shear strength tests of the soils with other types of geosynthetic reinforcement, such as geogrids, geonets $[23,24]$ as well as with the addition of dispersed reinforcement such as tire shreds [25] or dedicated to concrete reinforcement synthetic fibers [10,26-29].

In ordinary applications, the reinforced earth structures do not reach the damage condition. Therefore, to analyze the behaviour of the reinforced soil structure at the level of working stress, it is necessary to determine the mobilization of friction resistance and its relationships with the basic properties of the soil and the reinforcement [30]. It should be noted, however, that the interaction between the soil and the reinforcement would also depend on the response of the substrate on which the structure had been built. In the event of excessive ground settlements, too much deformation of the reinforcement may occur, which may result in exceeding the serviceability limit state. It should be noted that in the case of non-cohesive soils, the mechanism of interaction between reinforcement and soil is based on friction, which depends on the type of soil and reinforcement, and mainly on the roughness of its surface. Additionally, in case of sandy soils, there is a favorable mechanism of cooperation-grains interlocking in the structure of some geotextiles. Another form of cooperation is observed in cohesive soils where, in addition to friction, adhesion phenomena are observed on the 
contact with the reinforcement. The amount of adhesion is affected by the soil grain composition, but also by the roughness of the reinforcement surface and the moisture conditions.

A separate problem is the lack of description of the cooperation between medium-grained ash-slag mixtures and geosynthetics. These mixtures, classified as anthropogenic soils, are characterized by high values of the shear strength parameters-the angle of internal friction and cohesion [11,31,32]. Therefore, the interpretation of the behaviour of the ash-slag mixtures on contact with the geosynthetics should be similar as for cohesive soils. On the other hand, the specific structure of waste grains, which are generated from non-flammable substances in the coal combustion process, should be pointed out. Grains of fly ashes and ash-slag mixtures have irregular shapes, and there are also elongated grains with sharp edges. Coarser fractions of these wastes are usually full inside, but there are also grains which are empty or filled with finer spherical grains [33-35].

Colliery wastes, mainly medium-grained, are increasingly used in road construction to build embankments [11,36,37], which are stabilized with hydraulic binders [38]. They are also used as materials to stabilize weak soil [39-42]. However, there is no literature describing the interaction on the contact between the ash-slag mixture and geosynthetics. Usually, there are tests on the friction resistance between fly ashes (i.e., fine-grained colliery wastes used as sealing layers) and geomembranes [32] or other geosynthetics [43]. While designing the reinforced soil structures using ash-slag mixtures, the same rules which apply when designing structures from mineral soils are adopted. The fact that these wastes are materials that have a complex structural composition (as a result of using various coal combustion processes in power plants and combined heat and power plants) is ignored.

For design purposes, the resistance of the structure to slippage, after its geosynthetic reinforcement, can be taken based on the direct slip ratio [17]:

$$
\alpha_{d s}=\overline{\alpha_{s}} \frac{\tan \delta}{\tan \varphi}+\left(1-\overline{a_{s}}\right)(-)
$$

where $\delta\left(^{\circ}\right)$ is the angle of interfacial friction at the contact of the soil and the flat surface of the reinforcement, $\varphi\left({ }^{\circ}\right)$ is the angle of internal friction of the soil, and $\overline{a_{S}}(-)$ is the coefficient of the effective surface of the reinforcement in the shear plane.

The second parameter to be determined is the adhesion coefficient, which depends on the surface friction between the reinforcement and the soil:

$$
\alpha_{b}=\overline{\alpha_{s}} \cdot \frac{\tan \delta}{\tan \varphi}+\left(\frac{\sigma_{b}}{\sigma_{n}}\right) \cdot\left(\frac{\overline{a_{b}} \cdot B}{2 S}\right) \cdot \frac{1}{\tan \varphi}(-)
$$

where $\delta, \varphi, \overline{\alpha_{s}}$ are as above, $\overline{a_{b}}(-)$ is the coefficient of the effective surface of the reinforcement in a plane perpendicular to the pull-out direction, $B, S(\mathrm{~m})$ are dimensions of the ribs in the case of reinforcement with a net, and $\frac{\sigma_{b}}{\sigma_{n}}(-)$ is the ratio of the soil resistance to the stress acting perpendicularly to the reinforcement surface.

For nonwoven and woven geotextiles, it can be assumed that $\overline{\alpha_{s}}=1$ and $\overline{\alpha_{b}}=0$, so the coefficients of direct slip and adhesion for these materials are equal and most often range from 0.6 to 1.0 [44,45]. As already demonstrated, tests in a direct shear apparatus are appropriate for determining the direct slide coefficient between the soil and any reinforcement. Meanwhile, pull-out tests describe the development of adhesion. However, with regard to geotextiles, the adhesion mechanism is similar to the one that occurs with a direct slip.

As can be seen from Equations (1) and (2), the influence of adhesion is neglected in the calculations. Such an assumption can be regarded as correct due to the fact that the friction resistance plays a fundamental role in transferring tension stresses to the reinforcement and depends on normal stresses. This issue is the subject of many publications in which the use of non-linear Equations describing the frictional characteristics at the contact zone of geosynthetic with bulk material is proposed [46-49]. 
Meanwhile, Tanchaisawat et al. [50], after [51], indicated that the effectiveness of strengthening with geosynthetics should be determined due to the friction resistance and cohesion:

$$
\begin{gathered}
E_{c}=\left(\frac{c_{a}}{c}\right) \cdot 100(\%) \\
E_{\varphi}=\left(\frac{\tan \delta}{\tan \varphi}\right) \cdot 100(\%)
\end{gathered}
$$

where $E_{c}(\%)$ is the effectiveness of strengthening with geosynthetic due to cohesion, $E_{\varphi}(\%)$ is the effectiveness of strengthening with geosynthetic due to friction resistance, $c_{a}(\mathrm{kPa})$ is the adhesion between the soil and geosynthetic, $c(\mathrm{kPa})$ is the soil cohesion, $\delta\left(^{\circ}\right)$ is the angle of interfacial friction, and $\varphi\left({ }^{\circ}\right)$ is the angle of internal friction of the soil.

The comparison of test results of soil shear strength parameters and friction parameters on the interface between soil and geosynthetic $[4,6,52-54]$ indicates that the values of the parameters $E_{\varphi}$ and $E_{c}$ are within a wide range (from 0.41 to 1.15 and from 0.45 to 1.41 , respectively), but they are generally smaller than the value of 1.0. However, it should be noted that the usefulness of the $E_{c}$ parameter seems disputable (questionable) in the case when tested soil is non cohesive.

It is also possible to determine the interaction coefficient defined as the shear strength ratio at the contact of the filling material and the geosynthetic to the shear strength of the material itself $[50,53]$ :

$$
R_{i}=\frac{\tau_{f}}{\tau_{f a}}=\frac{\sigma_{n} \cdot \tan \delta+c_{a}}{\sigma_{n} \cdot \tan \varphi+c}(-)
$$

where $\tau_{f}(\mathrm{kPa})$ is shear strength, $\tau_{f a}(\mathrm{kPa})$ is interfacial friction resistance, $\sigma_{n}(\mathrm{kPa})$ is the normal stresses, $\delta\left({ }^{\circ}\right)$ is the angle of interfacial friction, $\varphi\left[^{\circ}\right]$ is the angle of internal friction of the soil, $c_{a}(\mathrm{kPa})$ is the adhesion between the soil and geosynthetic, and $c(\mathrm{kPa})$ is the soil cohesion.

The results of the research of Tanchaisawat et al. [50], Chai and Saito [53], Jotinsankasa and Rurgchaisri [4] show that the values of the interaction coefficient are usually less than 1.0 (0.3-1.1), whereas smaller values are usually obtained for cohesive soils.

The interfacial friction resistance tests should be performed for each type of geosynthetic and backfill material. The effect of soil compaction on its shear strength is well known. On the other hand, the results of friction resistance tests (among others [6,52]) indicate that the impact of compaction is not always clear and depends on the type of backfill and geotextile. Another engineering problem that occurs is related to the exploitation conditions. In the periods of rainfall, the degree of saturation (moisture content) of soil changes, and as a result the interfacial friction resistance between soil and geosynthetic can also change.

The purpose of the work was to determine the influence of compaction and water-saturation on the parameters of the shear strength of the ash-slag mixture taken from the landfill of the Heat and Power Plant located in Kraków (Poland) and the parameters of the friction resistance at the contact between the ash-slag mixture, and a nonwoven and a woven geotextile. The aim of the study arises from the need to search for materials other than mineral soils (the amount of which is limited) that can potentially be used as backfill material in earth-made constructions built with soil reinforced technology. As shown above, in the available literature, there are a number of coefficients that describe the interaction of geosynthetic with soil. Therefore, the study analyses the impact of the obtained values of the shear strength and friction resistance parameters of ash-slag mixture on the values of selected coefficients.

\section{Test Methods}

Basic physical properties and compactibility parameters of the ash-slag mixture were determined by standard methods. The granulometric composition was determined by the combined method [55]; that is, the sieve method for grains larger than $0.063 \mathrm{~mm}$ and the areometric method for smaller 
particles. The density of solid particles was determined by the method of a volumetric flask [56]. The compactibility parameters were determined in a Proctor's apparatus, in a cylinder with a volume of $2.2 \mathrm{dm}^{3}$ at a compaction energy of $0.59 \mathrm{~J} \mathrm{~cm}^{-3}$ [57].

The tests of shear strength and interfacial friction resistance were carried out in the direct shear apparatus [58] in a box with a $100 \times 100 \mathrm{~mm}$ cross-section and a sample height of $41 \mathrm{~mm}$ (shear strength) and $27 \mathrm{~mm}$ (interfacial friction resistance) with 5 intermediate frames forming a $10 \mathrm{~mm}$ thick shearing zone (Figure 1). The use of intermediate frames makes possible zonal cutting, limiting the effect of grains interlocking and wedging on the value of cohesion (Figure 2a). Samples for testing were compacted directly in the apparatus box at the optimum moisture content until a degree of compaction $\left(I_{S}\right)$ equaled 0.90 or 1.00 .

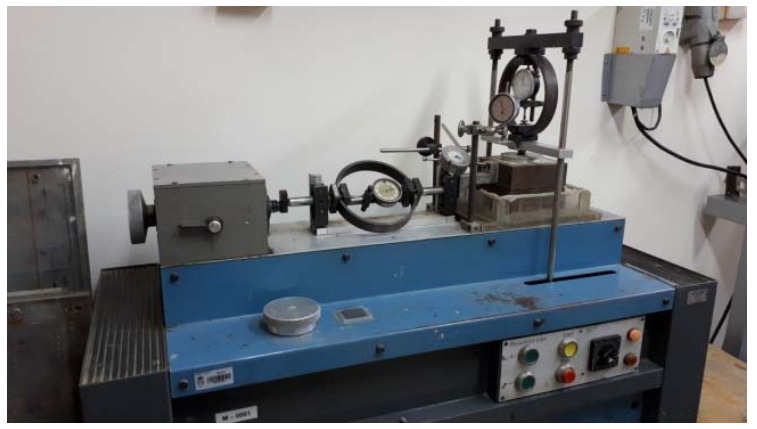

(a)

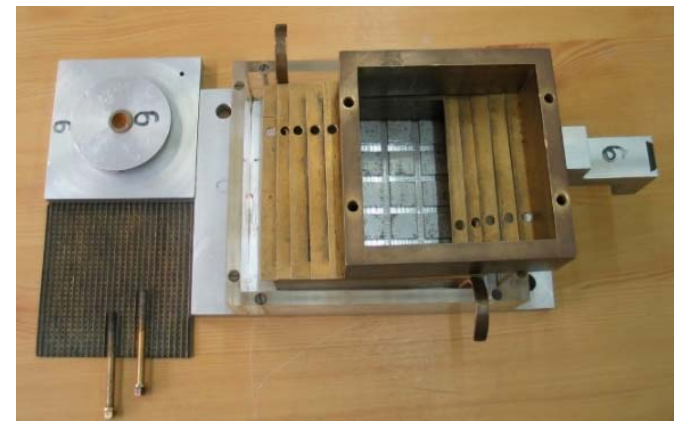

(b)

Figure 1. View of the direct shear apparatus (a) and elements of its two-part box (b).

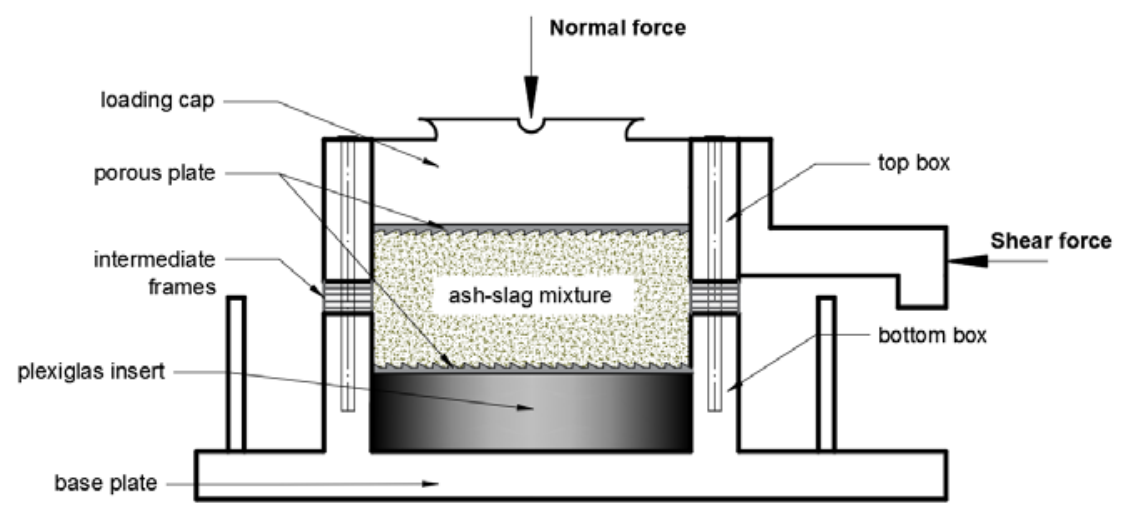

(a)

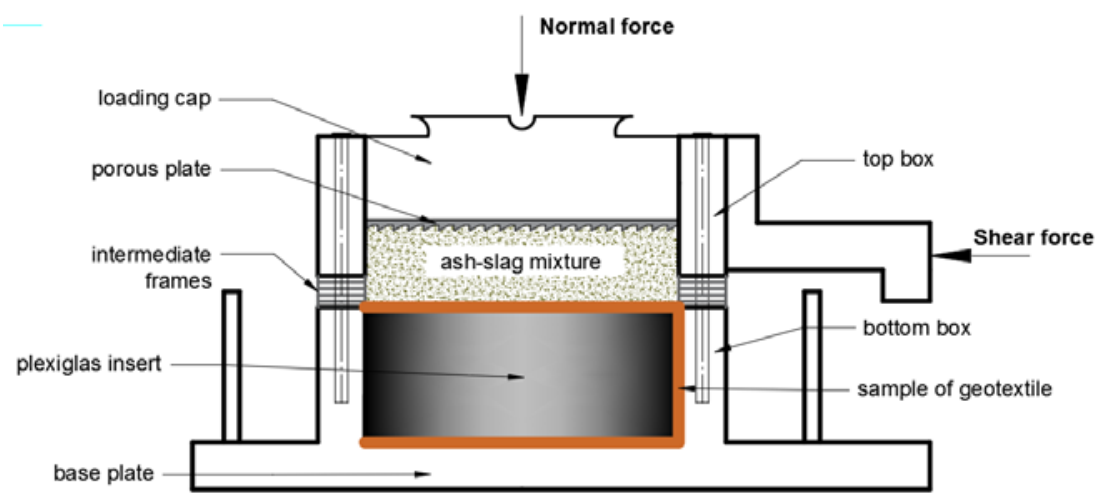

(b)

Figure 2. Scheme of the direct shear apparatus box-for shear strength tests (a) and for interfacial friction resistance tests $(\mathbf{b})$. 
After moulding, the samples were consolidated for $15 \mathrm{~min}$ at the vertical load of 50, 75, 100, 150, 200 , and $300 \mathrm{kPa}$, and then sheared at the speed of $0.2 \mathrm{~mm} \cdot \mathrm{min}^{-1}$. In the case of the interfacial friction resistance tests, the lower part of the box was filled with a Plexiglas insert, around which a geotextile sample was fixed at the height corresponding to the lower surface of the shearing zone and a sample of the mixture was formed on it (Figure $2 b$ ).

The shear strength and interfacial friction resistance tests were also performed on the samples initially saturated by immersing the box in water for $1 \mathrm{~h}$, and then sheared off when the shear zone was water-saturated.

The calculations of shear strength $\left(\tau_{f}\right)$ and interfacial friction resistance $\left(\tau_{f a}\right)$ parameters were performed using the least squares method [59], based on the linear Coulomb Equation:

$$
\tau_{f}\left(\tau_{f a}\right)=\sigma_{n} \cdot \tan \phi(\delta)+c\left(c_{a}\right)(k P a)
$$

where $\sigma_{n}(\mathrm{kPa})$ is the normal stress, $\varphi,(\delta)\left(^{\circ}\right)$ is the angle of internal friction (angle of interfacial friction), and $c,\left(c_{a}\right)(\mathrm{kPa})$ is cohesion (adhesion).

The maximum value of the shear stress was assumed as the shear strength criterion. The calculations of tested parameters also included the determination of the values of average standard deviations of tested the parameters.

\section{Characteristics of the Tested Materials}

According to the geotechnical nomenclature [60], the ash-slag mixture with a grain size less than $10 \mathrm{~mm}$ was classified as multifractional silty fine sand (siFSa). The basic properties of the mixture are shown in a Table 1.

Table 1. Geotechnical characteristics of the ash-slag mixture (own research).

\begin{tabular}{|c|c|}
\hline Parameter & Value \\
\hline Fraction content $(\%)$ : & \\
\hline - gravel, Gr: $63-2 \mathrm{~mm}$ & 17.9 \\
\hline - sand, Sa: $2-0.063 \mathrm{~mm}$ & 47.8 \\
\hline — silt, Si: $0.063-0.002 \mathrm{~mm}$ & 31.0 \\
\hline - clay, $\mathrm{Cl}:<0.002 \mathrm{~mm}$ & 3.3 \\
\hline Name acc. to [60] & Silty fine sand (siFSa) \\
\hline Uniformity coefficient (-) & 16.36 \\
\hline Optimum moisture content (\%) & 37.80 \\
\hline Maximum dry density $\left(\mathrm{g} \cdot \mathrm{cm}^{-3}\right)$ & 1.14 \\
\hline Dry density of solid particles $\left(\mathrm{g} \cdot \mathrm{cm}^{-3}\right)$ & 2.40 \\
\hline
\end{tabular}

The adhesion of geotextiles to the backfill layer or their slide depends on the type of product that was used. The values of coefficients describing adhesion and sliding on a woven or nonwoven geotextile depend on the technology of their production and surface roughness, but also on the granulation of the backfill, the shape of its grains and their roundness. The tests of interfacial friction resistance on the contact of the ash-slag mixture and the geosynthetic were performed with the use of the nonwoven and woven geotextiles (Figure 3). These geotextiles differ in physical and mechanical properties (Table 2), which is the result of the type of raw material of which they were made. The differences are particularly visible in tensile strength parameters.

The nonwoven geotextile is made of fleece built of polypropylene staple fibers, obtained by aerodynamic molding, subjected to a mechanical needling and then calendered-as a result, the fibers were pressed (Figure 3a). This process affects the gluing of fibers located on the surface of the fleece and, depending on the pressure, improves the strength and structure of the nonwoven geotextile surface. In the case of the geotextile that was used, the calendering process was carried out using less pressure, 
which caused the nonwoven fabric to be less welded, and thus softer and more fluffy. The geotextile that was used has isotropic properties, so its strength is the same in both directions. This material is diffusion-open, allowing the free flow of water and air. The nonwoven fabric is used in transportation engineering for strengthening the upper layers of the subgrade of unpaved roads and railway surfaces, and the construction of temporary, forestry, agricultural and hydrotechnical roads as separation layers.

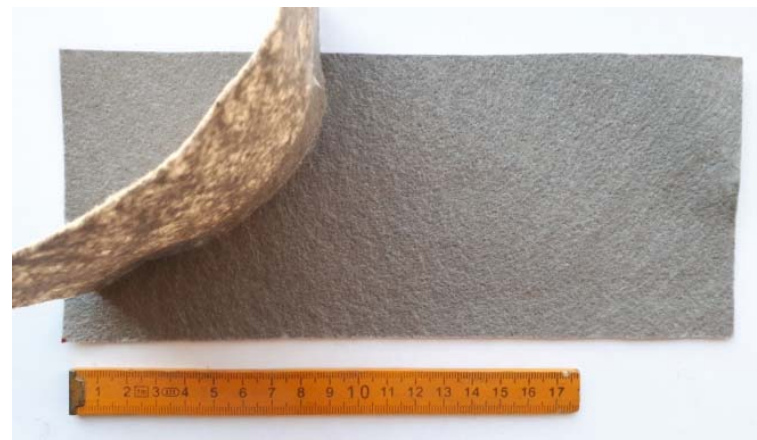

(a)

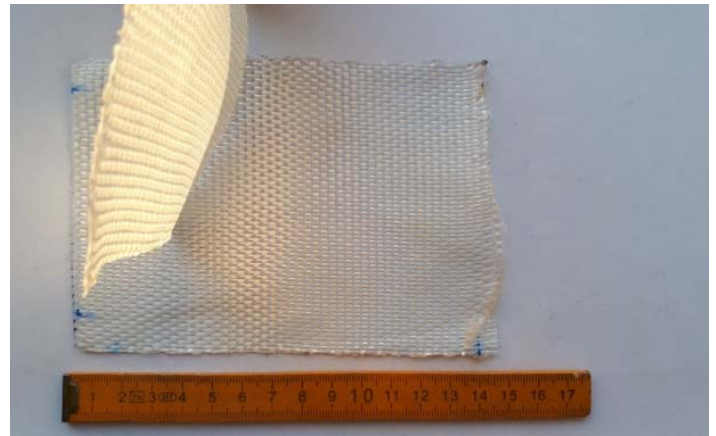

(b)

Figure 3. View of the nonwoven (a) and woven (b) geotextiles.

Table 2. Technical parameters of geotextiles (own study after product data sheet).

\begin{tabular}{lcc}
\hline \multirow{2}{*}{ Parameter } & \multicolumn{2}{c}{ Kind of Geotextiles } \\
\cline { 2 - 3 } & Nonwoven & Woven \\
\hline Kind of raw material & polypropylene & polyester \\
\hline CBR puncture force $(\mathrm{N})$ & 2500 & - \\
\hline Tensile strength $\left(\mathrm{kN} \cdot \mathrm{m}^{-1}\right):$ & & \\
- lengthwise & 16 & 150 \\
- transversely & 16 & 45 \\
\hline$\quad$ Elongation at break $(\%):$ & & 9 \\
- lengthwise & 43 & 20 \\
- transversely & 50 & 300 \\
\hline$\quad$ Surface weight $\left(\mathrm{g} \cdot \mathrm{m}^{-2}\right)$ & 200 & \\
\hline
\end{tabular}

The woven geotextile (Figure $3 b$ ) is a woven fabric made of high-strength polyester fibres, which permanently take over tensile loads, already at small elongations. It has visible pores resulting from weaving. Due to the need to maintain the constancy of size and shape of the pores under the influence of external forces, in the case of the analyzed geotextile, a linen weave was used. Woven geotextiles are used in hydrotechnical engineering, as well as for sealing landfills. The material does not decompose in the soil and water environment, it is characterized by a greater resistance to UV radiation, and also retains its properties at negative temperatures.

\section{Results of Tests and Calculations}

\subsection{Shear Strength and Interfacial Friction Resistance}

Figures 4 and 5 show the dependence of the shear stresses on the horizontal deformation of the samples at different normal stresses. In the case of testing the ash-slag mixture in conditions without water-saturation of the samples, a brittle cut was observed. The maximum value of the shear stress was obtained at the deformation of the sample ranging from $1 \%$ to $3 \%$. In the tests of the water-saturated samples, no maximum shear stress was observed, so the cutting was plastic. In this case, the shear stresses generally increased continuously; however, at some normal stresses, their stabilization could be observed or a slight decrease at the horizontal deformation in the range from $1 \%$ to $3 \%$. 

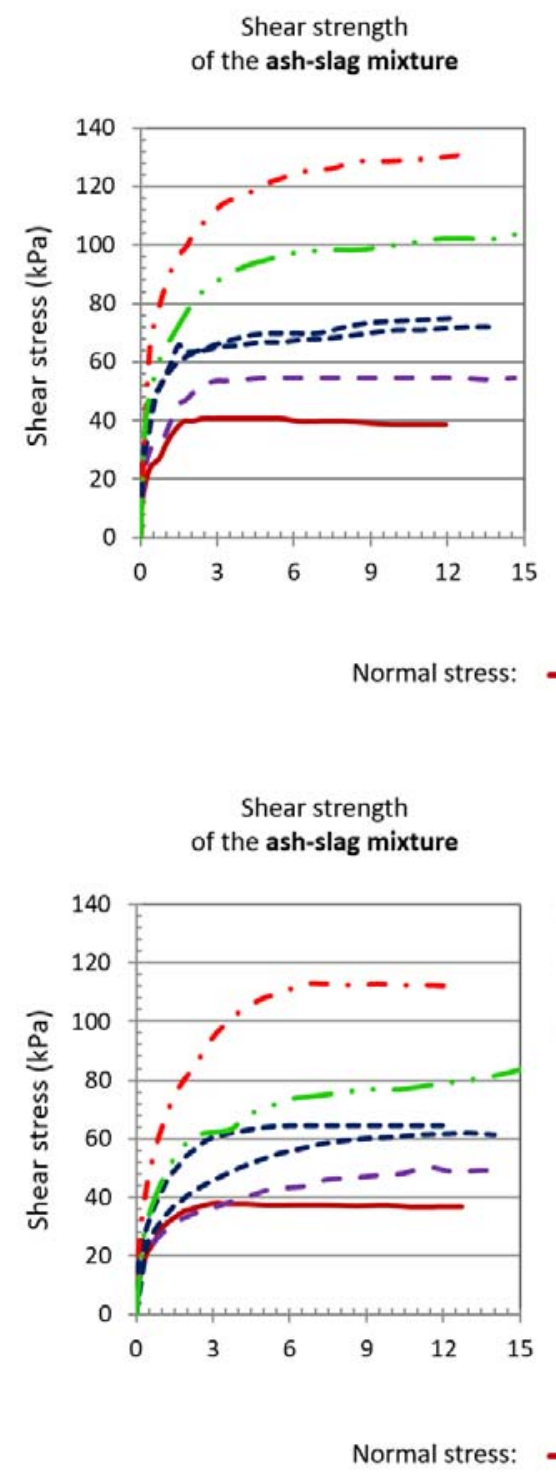

Interfacial friction resistance at the contact of ash-slag mixture and: nonwoven geotextile woven geoetxtile
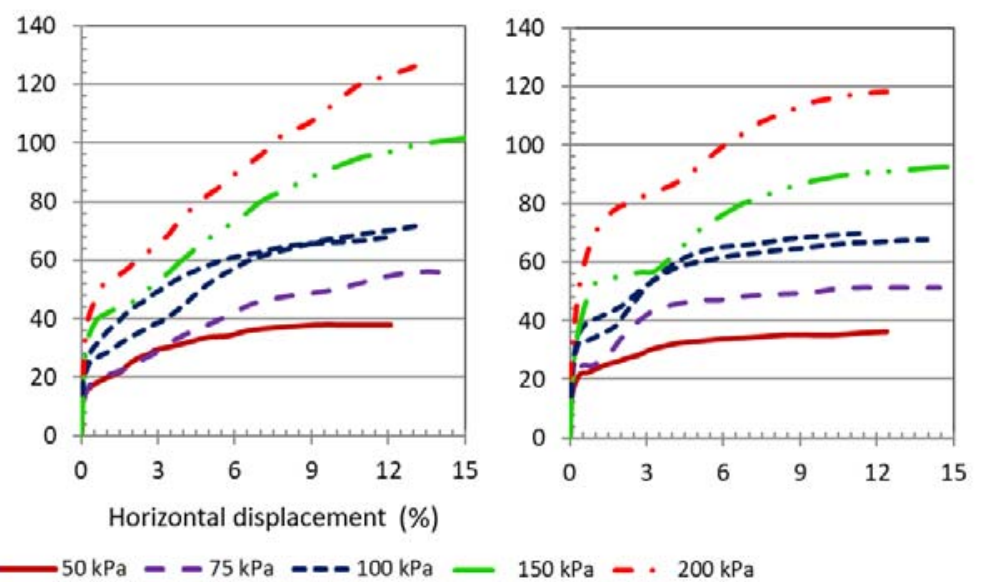

(a)

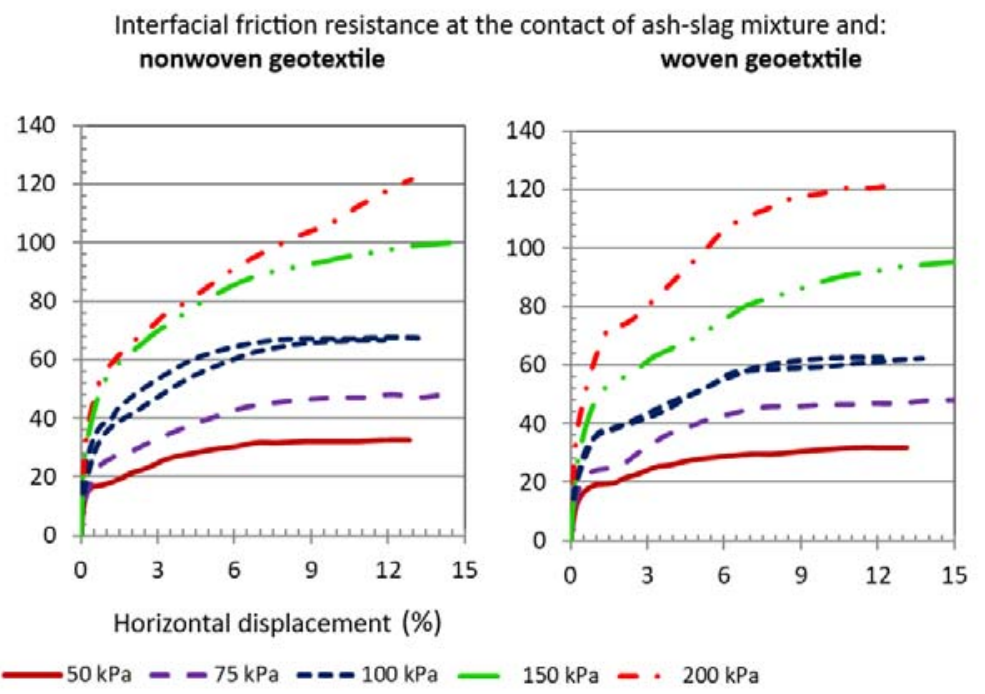

(b)

Figure 4. Changes in shear stress along with horizontal displacement of the samples at the degree of compaction $I_{S}=0.90$. (a) unsaturated samples; (b) saturated samples.

In the tests of the interfacial friction resistance, both with and without water-saturation, the shearing of the samples was plastic for both geotextiles. It was also observed that for both types of geotextile, as expected, the deformation of the sample required for mobilisation of the friction resistance increased with the increase in normal stress.

A different relationship was found by Anubhav and Basudhar [23], where the tested nonwovens were characterized by a brittle cut at the contact with the monofractional sand. The results of shear strength and interfacial friction resistance parameters obtained by them make it possible to state that in the case of non-cohesive soils, such dependence can be expected. However, in the case of cohesive soils, the adhesion resistance will result in plastic shearing, with a tendency to stabilisation of the shear stresses in the final phase of shearing. Therefore, it can be concluded that the changes in shear stresses, together with the increase in the horizontal deformation of the samples in the tests of frictional resistance, will depend to a large extent on the material of the backfill. 

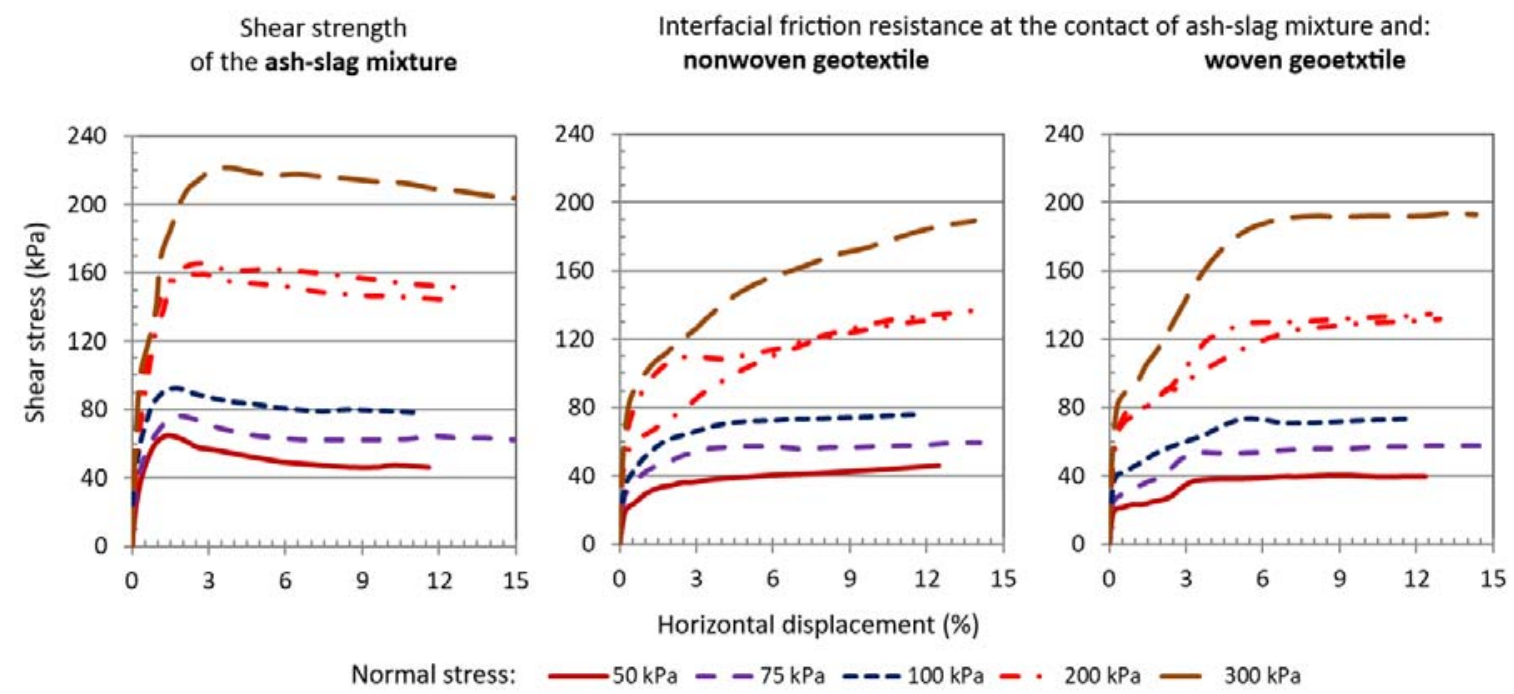

(a)
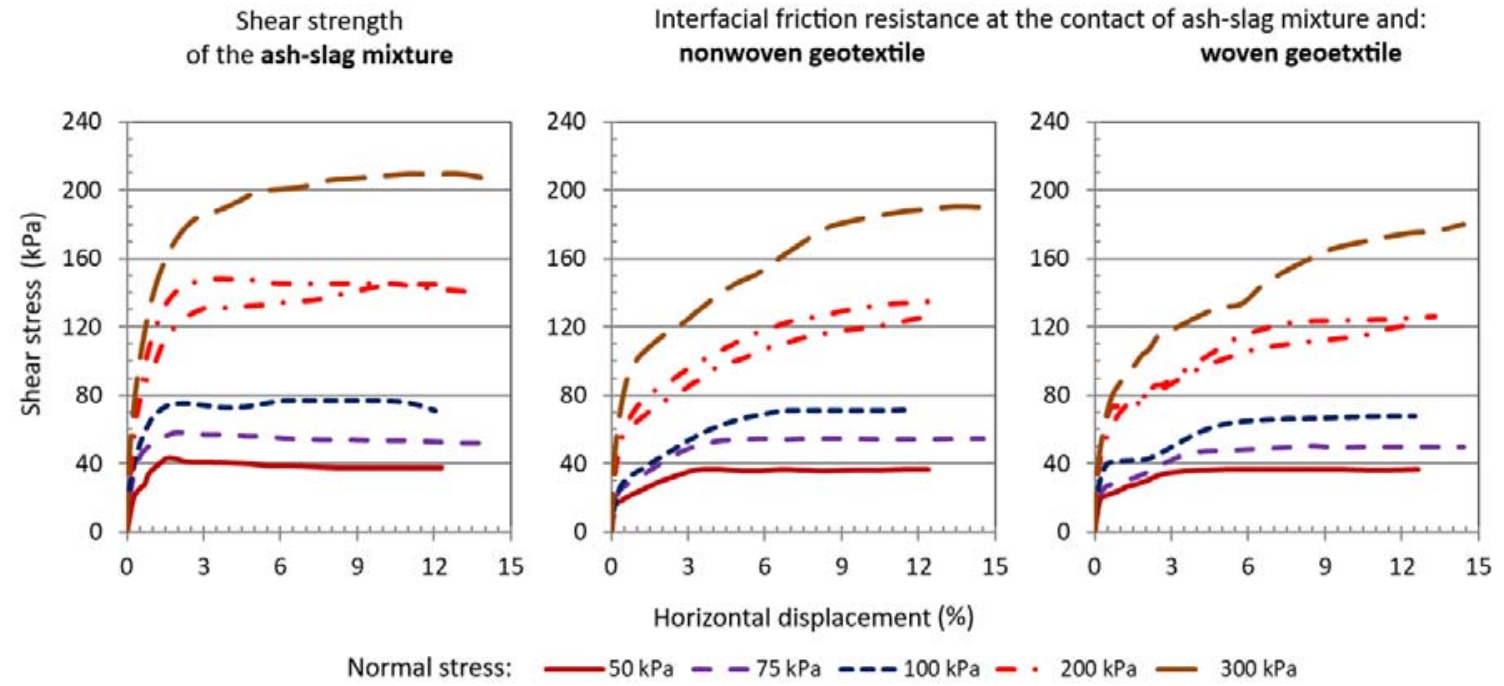

(b)

Figure 5. Changes in the tangential stresses along with the horizontal deformation of the samples at the degree of compaction $I_{S}=1.00$. (a) unsaturated samples; (b) saturated samples.

It is worth noting that in the presented results of interfacial friction resistance tests, the shear stresses in the water-saturated samples were only slightly lower than the corresponding stresses in the unsaturated samples. This small difference may result from the phenomenon of sucking between the geotextiles and the ash-slag mixture, as well as from the geotechnical properties of the ash-slag mixture. A similar behaviour of a nonwoven fabric was noted in the research of Bergado et al. [22], who even obtained a slight increase in shear stresses in the tests with water-saturation.

The increase in compaction from $I_{S}=0.90$ to 1.00 caused an increase, and the water-saturation of the samples caused a decrease, in the shear strength of the ash-slag mixture and in the interfacial friction resistance on the contact of the mixture and the nonwoven and woven geotextiles.

In the case of testing the friction resistance of the unsaturated ash-slag mixture samples, at the contact with the woven geotextile, at the increase in the degree of compaction from $I_{S}=0.90$ to 1.00 , the interfacial friction resistance increased by $8(24 \%)$ and $14 \mathrm{kPa}(12 \%)$ at the normal stresses equal to 50 and $200 \mathrm{kPa}$, respectively. In the tests of the saturated samples at the normal stresses equal to 50 and $200 \mathrm{kPa}$, the increase in interfacial friction resistance was $5(15 \%)$ and $10 \mathrm{kPa}(9 \%)$, respectively. 
The water-saturation of the ash-slag mixture resulted in the decrease in the interfacial friction resistance from $1 \%$ to $6 \%$ at the degree of compaction $I_{S}=0.90$ and from $5 \%$ to $12 \%$ at the degree of compaction $I_{S}=1.00$.

In the case of the ash-slag mixture tests without water-saturation, at the normal stresses equal to $50 \mathrm{kPa}$, the shear strength increased by $16 \mathrm{kPa}(34 \%)$, and, at the stresses $200 \mathrm{kPa}$, by $19 \mathrm{kPa}$ (14\%) (Figure 6). In the case of testing the water-saturated samples, at the normal stresses equal to 50 and $200 \mathrm{kPa}$, the increase in the shear strength was $12 \mathrm{kPa}(29 \%)$ and $20 \mathrm{kPa}(16 \%)$, respectively. The water-saturation of the samples caused the decrease in the shear strength from $8 \%$ to $19 \%$, relative at both degrees of compaction.
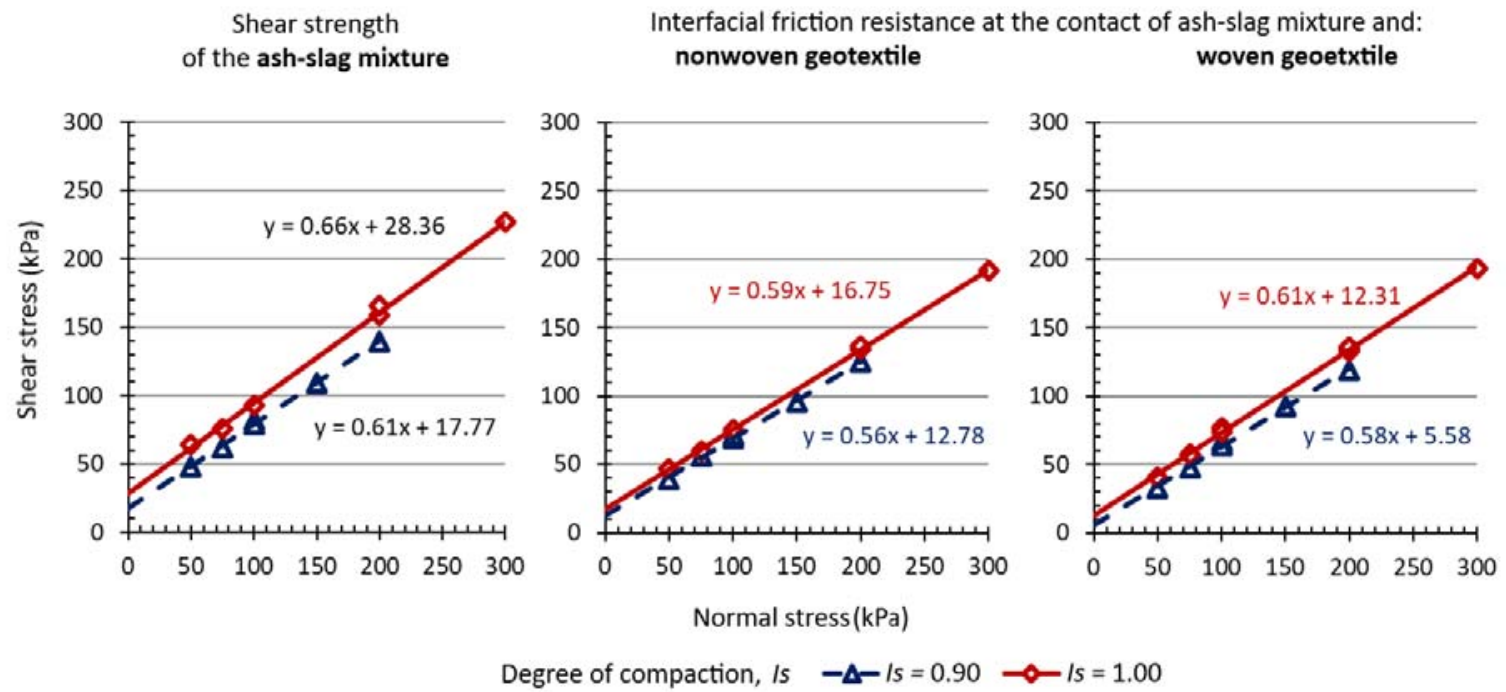

(a)
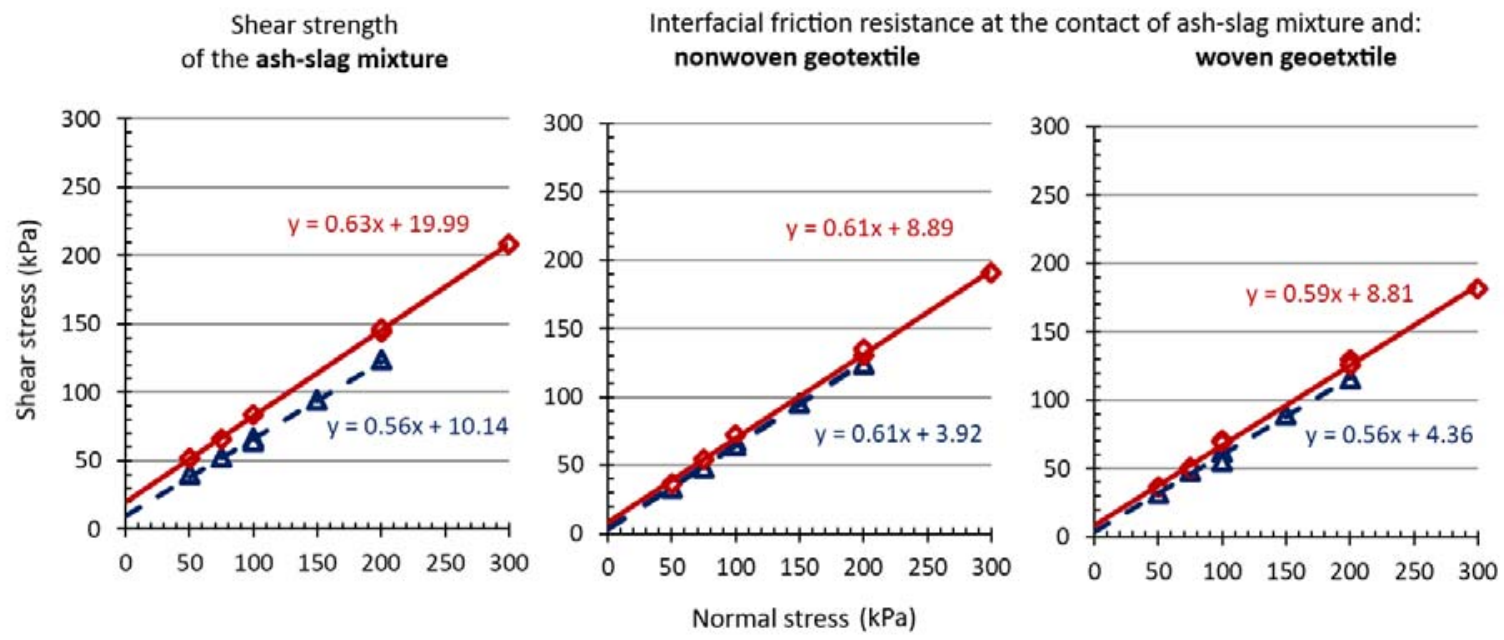

Degree of compaction, is $-\Delta-1 s=0.90 \multimap-1 s=1.00$

(b)

Figure 6. Tangential stress versus normal stress in the shear strength and interfacial friction resistance tests, at the different compaction of the unsaturated and water-saturated samples. (a) unsaturated samples; (b) saturated samples.

In the tests of friction resistance at the contact of the ash-slag mixture with the nonwoven geotextile in conditions without water-saturation, the resistance increased by $8 \mathrm{kPa}(20 \%$ relative) at the normal stresses equal to $50 \mathrm{kPa}$, and by $9 \mathrm{kPa}(7 \%)$ at the normal stresses equal to $200 \mathrm{kPa}$, with the increase 
in the degree of compaction from $I_{S}=0.90$ to 1.00. Meanwhile, in the tests with water-saturation of the samples at the normal stresses equal to 50 and $200 \mathrm{kPa}$, the increase in interfacial friction resistance was $4(11 \%)$ and $6 \mathrm{kPa}(5 \%)$, respectively. Water-saturation of the shearing zone of the samples caused the decrease of the interfacial friction resistance from $14 \%$ to $1 \%$ at the degree of compaction $I_{S}=0.90$, and from $20 \%$ to $1 \%$ at the degree of compaction $I_{S}=1.00$, with the increase in normal stresses from 50 to $300 \mathrm{kPa}$. This relationship is consistent with results presented by Noorzad and Mirmoradi [61], Khoury et al. [62], Cahi and Saito [53] or Jotisankasa and Rurgchaisiri [4] obtained for different soils and geotextiles, and it is consistent with the theory of shear strength of unsaturated soils [63]. Theory and test results indicate that the presence of suction stress within unsaturated soil causes its shear strength to be higher than that of saturated soil. So, the same relationship can be expected when the friction resistance between the unsaturated soil and the geotextile is considered. Vahedifard et al. [64] indicated that suction stress can significantly increase the shear strength at the contact of the soil and reinforcement, as well as can reduce the load mobilized in the geotextile.

The analysis of Figures 4-6 shows that the interfacial friction resistance values were lower than the shear strength of the ash-slag mixture. This phenomenon was also found by Vieira et al. [65] and Punetha et al. [6], who indicated that this is most likely the result of loosening the soil over the geotextiles, due to the suppression of soil settlement by it. This relation may also result from the surface roughness of geotextiles and their surface mass. Because of the production process, the geotextile surface is more homogeneous than the soil surface, which consists of particles of various diameters and shape.

\subsection{Parameters of Shear Strength and Interfacial Friction}

The parameters of the shear strength, i.e., the angle of internal friction and cohesion of the ash-slag mixture, increased with the increase in compaction. In the case of the unsaturated samples, the increase in the angle of internal friction was over $2^{\circ}$ (7\%) (Figure 7a), and, in cohesion, of around $11 \mathrm{kPa}$ $(60 \%)$ (Figure $7 \mathrm{~b})$; meanwhile, in the case of the water-saturated samples, the angle of internal friction increased by $3^{\circ}(9 \%)$, and cohesion increased by $10 \mathrm{kPa}$ (twice) at the degree of compaction $I_{S}=0.90$ and 1.00 , respectively.

With the increase in the degree of compaction from $I_{S}=0.90$ to 1.00 , the interfacial friction angle at the contact with the nonwoven geotextile increased by $1^{\circ}(4 \%)$ in the tests without saturation and by $1.5^{\circ}(5 \%)$ in the tests with water-saturation. The adhesion increased with the increase in the compaction by $4 \mathrm{kPa}$ in the tests without saturation and by $5 \mathrm{kPa}$ in the tests with water-saturation-the increase was by $31 \%$ and $127 \%$.

With the increase in the degree of compaction from $I_{S}=0.90$ to 1.00 , the interfacial friction angle at the contact with the woven geotextile increased by over $1^{\circ}$, which was $5 \%$ and $4 \%$ in the tests of unsaturated and water-saturated samples, respectively. The adhesion increased at least twice as the compaction increased, i.e., by 7 and $5 \mathrm{kPa}$, in the tests of unsaturated and water-saturated samples, respectively.

The obtained results indicate that the water-saturation of the ash-slag mixture samples caused a significant decrease in its shear strength. The angle of internal friction decreased by an average of $2^{\circ}(6 \%$ and $4 \%)$ and the cohesion by $8 \mathrm{kPa}(43 \%$ and $23 \%)$ at both sample compaction $\left(I_{S}=0.90\right.$ and 1.00 , respectively).

A slightly different relationship was found for friction resistance parameters on contact with nonwoven geotextile. In this case, tests of friction resistance at the contact of the mixture and nonwoven geotextile water-saturation caused a slight increase in the value the interfacial friction angle by 2 and $1^{\circ}(6 \%$ and $4 \%)$ and decrease in the adhesion by 9 and $8 \mathrm{kPa}(69 \%$ and $47 \%)$ at the degree of compaction $I_{S}=0.90$ and 1.00 respectively. On the other hand, considering the interaction between the ash-slag mixture and woven geotextile, the water-saturation of the samples decreased the value of the interfacial friction angle by about $1^{\circ}(2 \%$ and $3 \%)$, and the adhesion by 1.5 and $3.5 \mathrm{kPa}(22 \%$ and $28 \%)$ respectively at $I_{S}=0.90$ and 1.00 . 
In the literature, interfacial friction resistance tests have usually been carried out for mineral soils, most often sandy ones. In those studies, it was shown that most often they are brittle cuts, so there are differences between the maximum and the residual interfacial friction resistance (among others [52,66]), which affects the obtained values of the angle of interfacial friction and adhesion. In the presented studies, no such dependence was noticed-the frictional resistance increased with increasing deformation of the sample, which may result from the roughness of the mixture grains and their meshing with the geosynthetic surface.

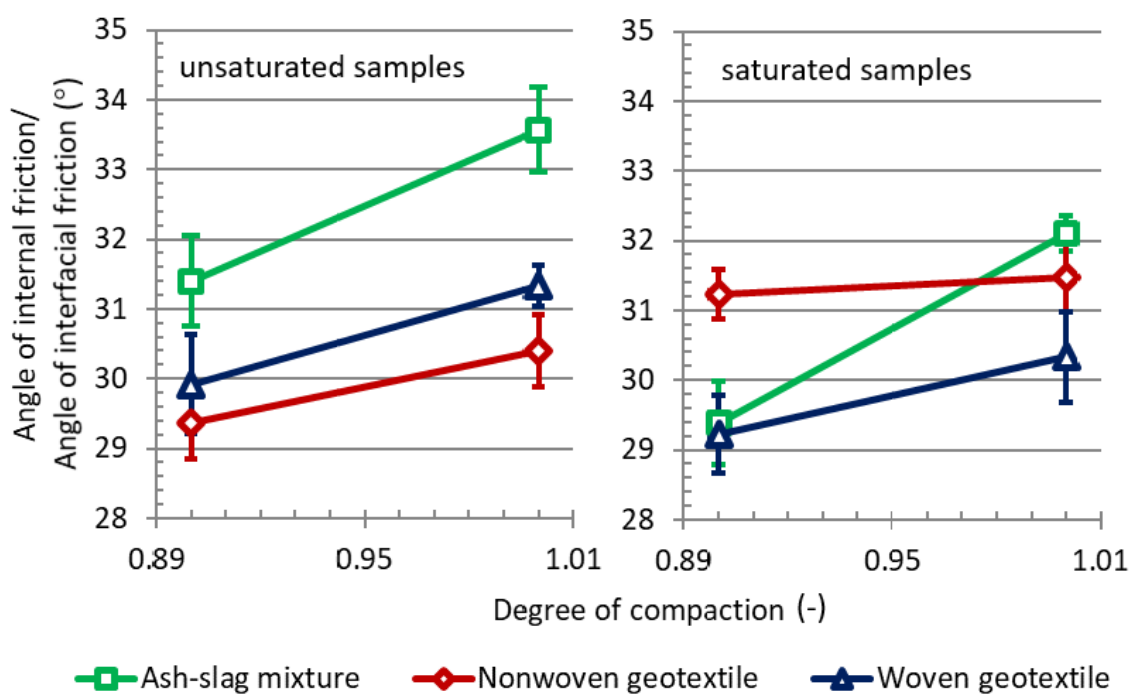

(a)

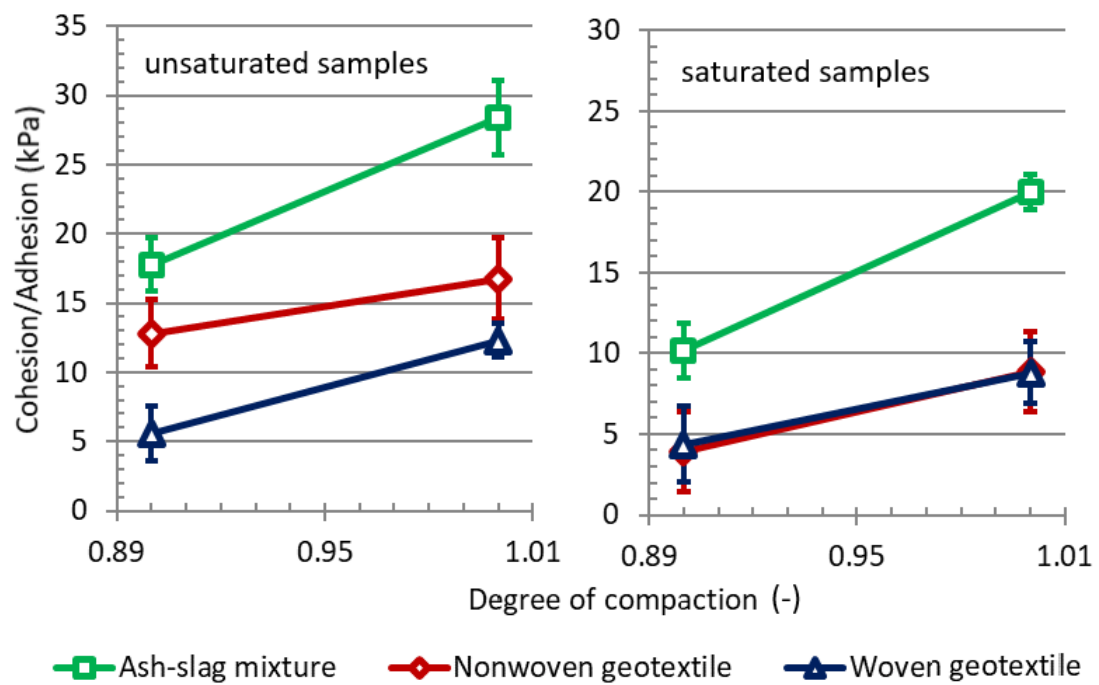

(b)

Figure 7. Shear strength and frictional resistance parameters with their average standard deviations versus compaction. (a) angle of internal friction and interfacial friction; (b) cohesion and adhesion.

In Figure 8, the values of the shear strength parameters of the ash-slag mixture and interfacial friction resistance at the contact of the mixture with geotextiles are compared. It was found that the angle of internal friction of the mixture at both compactions was greater than the angle of interfacial friction. Only the angle of interfacial friction on the contact with the nonwoven geotextile in the water-saturated samples was greater than the angle of internal friction. As already noted above, this could have been due to the effect of the suction pressure between the nonwoven fabric and the 
mixture. Comparing the values of the angle of interfacial friction at the contact of the mixture with the woven geotextile and the nonwoven geotextile, its higher values were found while testing the unsaturated samples.
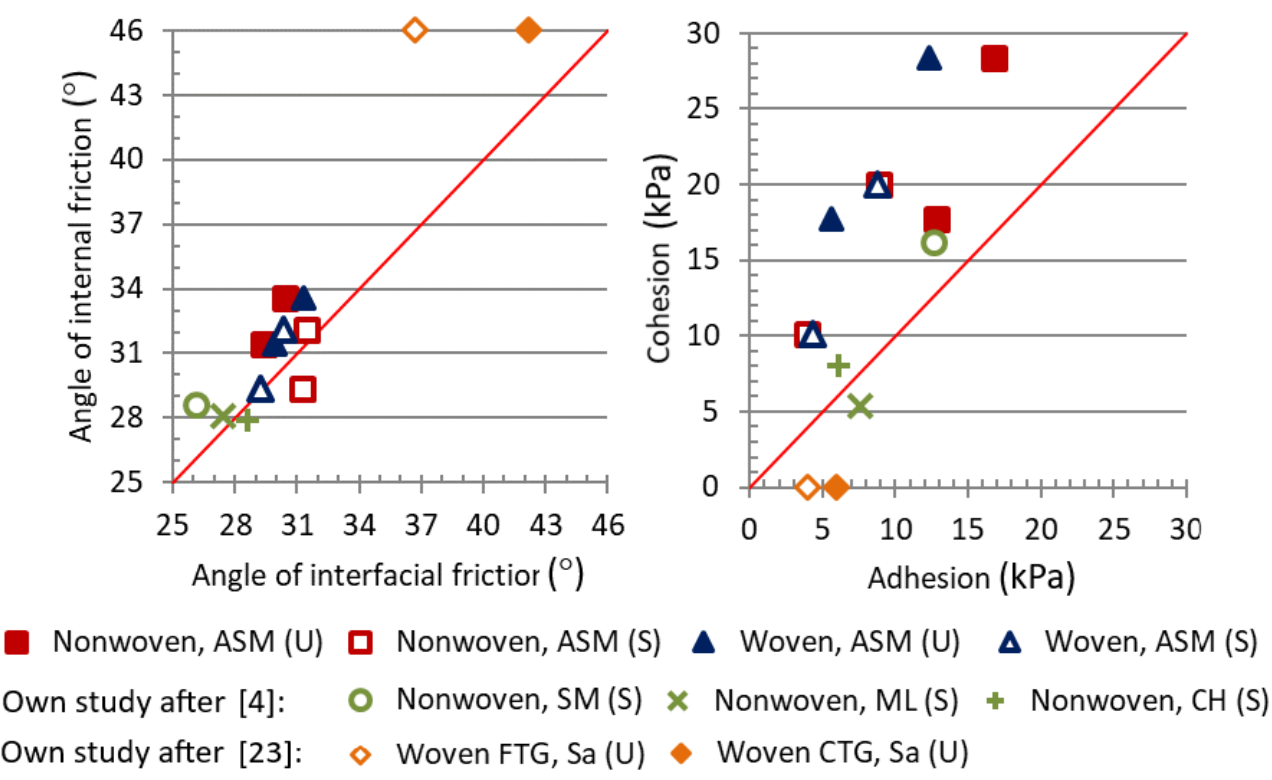

Figure 8. Relation between parameters that characterize shear strength and interfacial friction resistance.

The values of shear strength parameters of the tested ash-slag mixture were high, which is consistent with the research conducted for fuel waste by [31,32]. It can be noticed that the obtained values of the angle of internal friction are comparable to the values for sandy soils [10,31].

The cohesion of the ash-slag mixture was greater than the adhesion at the contact of the mixture and geotextiles. In contrast, the adhesion at the contact of the mixture with the nonwoven geotextile was greater than the adhesion at the contact of the mixture with the woven geotextile in the unsaturated samples. This results from the different surface structure of both geotextiles. As shown earlier (see Chapter 3), the surface of the nonwoven geotextile is calendered, which makes it more rough compared to the woven geotextile and increases the adhesion. In the tests of the water-saturated samples, the adhesion of the mixture at the contact with both geotextiles was similar. This results from the increased water content and therefore the moisturizing of both geotextiles, which, in the case of the woven geotextile, resulted in a reduction in its fluffiness and thus the value of adhesion.

Similar relations between the angle of internal and interfacial friction, as well as cohesion and adhesion, were obtained by Jotisankasa and Rurgchaisri [4] while testing three cohesive soils and in sand tests by Anubhav i Basudhar [23]. In their research, they showed a significant reduction in the friction resistance parameters on the contact with the woven geotextile compared to the shear strength parameters of the tested soils (Figure 8).

Figure description code: $\mathrm{ASM}=$ ash-slag mixture, $\mathrm{Sa}=$ sand, $\mathrm{SM}=$ silty sand, $\mathrm{ML}=$ silt, $\mathrm{CH}=$ clay, Nonwoven, Woven = type of geotextiles, CTG, FTG $=$ kind of woven [23], U = unsaturated samples, $\mathrm{S}=$ saturated samples.

\subsection{Cooperation and Effectiveness of Using a Geotextile}

It can be noticed that the effectiveness of the reinforcement resulting from the frictional resistance and cohesion due to the application of geosynthetics calculated by Equations (2) and (3) depended on the compaction and water-saturation of the samples. In the tests without water-saturation, a slightly higher efficiency resulting from the friction resistance was obtained for the woven geotextile, and from the cohesion resistance for the nonwoven geotextile. A reverse dependence was found in the tests of 
saturated samples (Table 3), but there were no significant differences in the effectiveness of cohesion between the two geotextiles in this case. Comparing the effectiveness while shearing unsaturated and water-saturated samples, its higher values were found in frictional resistance and significantly lower in cohesion resistance for the nonwoven geotextile. In the case of the woven geotextile, higher efficiency values were obtained due to the frictional resistance and cohesion in the tests of the water-saturated samples, but no large differences were obtained. Meanwhile, in the case of the nonwoven geotextile, higher values of the effectiveness of the increase in the friction resistance were obtained in the tests with water-saturation, and of the cohesion resistance in tests without water-saturation. This indicates that the woven geotextile was characterized by a better interaction with the ash-slag mixture under direct shear conditions, as well as was being less susceptible to changes in these properties due to the water-saturation. On the other hand, the non-woven geotextile exhibits higher values of both efficiency coefficients considering the test results for unsaturated as well as for saturated samples.

Table 3. The efficiency of strengthening with geotextiles in relation to the ash-slag mixture.

\begin{tabular}{|c|c|c|c|c|c|c|c|c|}
\hline \multirow{4}{*}{$\begin{array}{c}\text { Degree of } \\
\text { Compaction, } I_{S}(-)\end{array}$} & \multicolumn{2}{|c|}{$\begin{array}{l}\text { Nonwoven } \\
\text { Geotextile }\end{array}$} & \multicolumn{2}{|c|}{$\begin{array}{c}\text { Woven } \\
\text { Geotextile }\end{array}$} & \multicolumn{2}{|c|}{$\begin{array}{l}\text { Nonwoven } \\
\text { Geotextile }\end{array}$} & \multicolumn{2}{|c|}{$\begin{array}{c}\text { Woven } \\
\text { Geotextile }\end{array}$} \\
\hline & $E_{\varphi}$ & $E_{C}$ & $E_{\varphi}$ & $E_{C}$ & $E_{\varphi}$ & $E_{C}$ & $E_{\varphi}$ & $E_{C}$ \\
\hline & \multicolumn{8}{|c|}{$(\%)$} \\
\hline & \multicolumn{4}{|c|}{ Unsaturated Samples } & \multicolumn{4}{|c|}{ Water-Saturated Samples } \\
\hline 0.90 & 92.2 & 71.9 & 94.3 & 31.4 & 107.7 & 38.7 & 99.3 & 43.0 \\
\hline 1.00 & 88.4 & 59.1 & 91.7 & 43.4 & 102.3 & 44.5 & 93.3 & 44.1 \\
\hline
\end{tabular}

$E_{\varphi}$-efficiency of strengthening the friction resistance, $E_{C}$ - efficiency of strengthening cohesion.

The results of calculations of the geotextile strengthening effectiveness in relation to compaction are quite interesting. Regardless of whether the tests were conducted without or with water-saturation of the samples, higher efficiency values resulting from the friction resistance were obtained at a smaller compaction. In the case of cohesion resistance, higher efficiency values were obtained in studies without water-saturation. Increased compaction resulted in increased efficiency resulting from cohesion in the conditions without saturation and its reduction in the tests with water-saturation of the samples. This means that the use of geotextiles in the case of soils with lower shear strength parameters used as a bulk material in retaining structures or foundation of embankments on low-bearing soils should improve the stability of such structures.

The results of the interaction coefficient calculation using the Equation (5) are shown in the Table 4. It can be stated that the higher values of the $R_{i}$ were obtained in studies of non-woven geotextile than woven one. The obtained range of values of iteraction coefficient isn't very wide (from about 0.70 to 1.05 , mainly $0.8-1.0$ ) and it fits in the range of results reported by others $[4,50,53]$. The tests' results also indicate that the values of this coefficient increased with the increase in normal stresses (Figure 9). Higher values of this coefficient were obtained at the lower compactions and in the tests with water-saturation. A similar influence of soil saturation on the values of soil shear strength and resistance on the contact between the mineral soils and the geotextile was obtained by Jotisankasa and Rurgchaisri [4]. The authors conducted tests on samples of silty sand (SM), silt (ML) and clay (CH) formed, among others, at optimum moisture content, and then sheared in a direct shear apparatus without and with saturation. These studies have shown that the peak shear strength of saturated soil is very close to the value of resistance on the contact of the soil with the nonwoven geotextile. In turn, the peak values of unsaturated soil resistance on the contact with nonwoven geotextile were even three times lower than the shear strength of the soil. Figure 9 shows the values of the interaction factor calculated using Equation (5) for the results by Jotisankasaa and Rurgchaisri [4]. The calculation results for the tested soils are characterized by a similar relation, as in the case of the presented tests for the ash-slag mixture. Values of this coefficient were lower in case of saturated soil tests in relation to tests 
carried out in non-saturated conditions. Vahedifard et al. [64]'s analysis of geotextile-reinforced earth structures revealed that increase in the degree of soil saturation (decrease in suction stress) affects the increase in active earth pressures and, as a result, the load of reinforcement increases. Such behaviour of the soil can be, to some extent, an explanation as to why higher values of the interaction coefficient were obtained for water-saturated samples than for unsaturated ones.

Table 4. Coefficient of interaction of both geotextiles and the ash-slag mixture.

\begin{tabular}{|c|c|c|c|c|c|c|c|c|}
\hline \multirow{6}{*}{$\begin{array}{l}\text { Normal } \\
\text { Stresses, } \\
\sigma_{N}(\mathbf{k P a})\end{array}$} & \multicolumn{4}{|c|}{ Nonwoven Geotextile } & \multicolumn{4}{|c|}{ Woven Geotextile } \\
\hline & \multicolumn{8}{|c|}{ Samples } \\
\hline & \multicolumn{2}{|c|}{ Unsaturated } & \multicolumn{2}{|c|}{ Water-Saturated } & \multicolumn{2}{|c|}{ Unsaturated } & \multicolumn{2}{|c|}{ Water-Saturated } \\
\hline & \multicolumn{8}{|c|}{ Degree of Compaction, $I_{S}(-)$} \\
\hline & 0.90 & 1.00 & 0.90 & 1.00 & 0.90 & 1.00 & 0.90 & 1.00 \\
\hline & \multicolumn{8}{|c|}{ Interaction Coefficient, $R_{i}(-)$} \\
\hline 50 & 0.85 & 0.75 & 0.89 & 0.80 & 0.71 & 0.69 & 0.84 & 0.74 \\
\hline 100 & 0.88 & 0.80 & 0.97 & 0.88 & 0.80 & 0.77 & 0.91 & 0.81 \\
\hline 150 & 0.89 & 0.82 & 1.00 & 0.92 & 0.84 & 0.81 & 0.93 & 0.85 \\
\hline 200 & 0.90 & 0.83 & 1.02 & 0.94 & 0.86 & 0.83 & 0.95 & 0.87 \\
\hline 300 & 0.90 & 0.85 & 1.04 & 0.97 & 0.89 & 0.86 & 0.96 & 0.89 \\
\hline
\end{tabular}
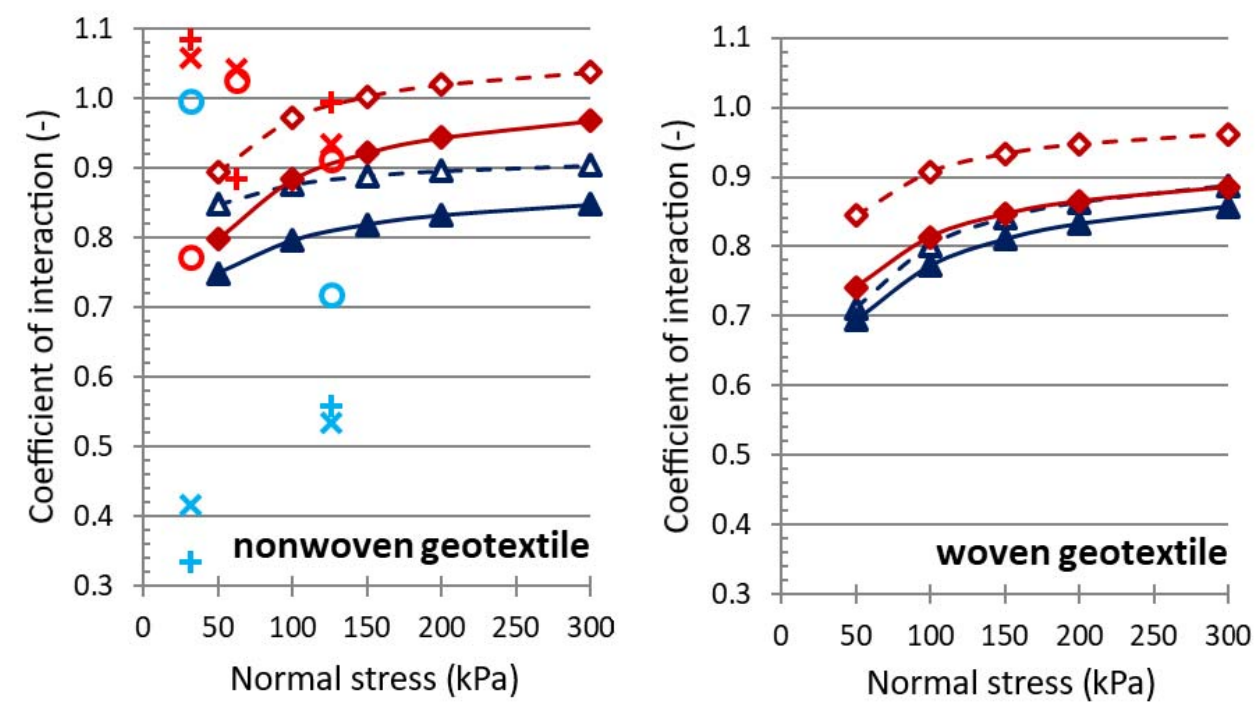

$$
\begin{aligned}
& -\Delta-\operatorname{ASM}(\mathrm{U}), I_{S}=0.90-\diamond-\operatorname{ASM}(\mathrm{S}), I_{S}=0.90-\mathrm{ASM}(\mathrm{U}), I_{S}=1.00-\mathrm{ASM}(\mathrm{S}), I_{S}=1.00 \\
& \text { Own study after [4]: } \quad \mathrm{SM}(\mathrm{U}) \times \mathrm{ML}(\mathrm{U})+\mathrm{CH}(\mathrm{U}) \circ \mathrm{SM}(\mathrm{S}) \times \mathrm{ML}(\mathrm{S})+\mathrm{CH}(\mathrm{S})
\end{aligned}
$$

Figure 9. Interaction coefficient versus normal stress. Figure description code: ASM = ash-slag mixture, $\mathrm{SM}=$ silty sand, $\mathrm{ML}=$ silt, $\mathrm{CH}=$ clay, $I_{S}=$ degree of compaction, $\mathrm{U}=$ unsaturated samples, $\mathrm{S}=$ saturated samples.

The influence of moisture content and the compaction of sand on shear strength values was also analyzed in detail by Punetha et al. [6]. While comparing the results of the research on dry sand and partially saturated sand, these authors stated that in unsaturated soil, the friction between grains and reinforcement occurs more often than when the soil is dry. In such soil, the grains slide on the geotextile surface during shearing. They did not notice any clear differences in the value of friction resistance on soil-geotextile contact in an unsaturated and saturated state. On the other hand, the results of tests on soils with different compaction allow to state that this parameter is very important in shear strength tests, and it can be of little importance when the soil-geotextile resistance is tested. Punetha et al. [6] 
explained that this relation is a result of the influence of the geotextile on limiting the dilatation and thus limiting the effect of compaction. In contrast, tests of Afzali-Nejad et al. [66] and Lashkari and Jamali [67] revealed that the interfacial friction between sand and woven or non-woven geotextiles increases with the density of sand.

\section{Conclusions}

On the basis of the experimental results obtained from the present investigations of the shear strength of the ash-slag mixture and the interfacial friction resistance at the contact between the ash-slag mixture and woven or nonwoven geotextiles, and the discussion made, the following conclusions can be drawn:

1. The parameters of the shear strength of the ash-slag mixture and the friction resistance at the contact of the mixture and the nonwoven or woven geotextiles were large.

2. The highest values of the tested parameters were obtained for higher compaction in conditions without water-saturation of the samples.

3. The test results confirmed the influence of compaction and water-saturation on the values of the tested parameters.

4. The increase in the compaction of the ash-slag mixture caused an increase of $7 \%$ to $9 \%$ relative angle of internal friction and $60 \%$ to $97 \%$ cohesion as well as $1 \%$ to $5 \%$ angle of interfacial friction and 31 to $127 \%$ relative adhesion.

5. The water-saturation of the samples decreased of $4 \%$ to $6 \%$ of the internal friction angle and $30 \%$ to $43 \%$ of cohesion. In contrast, the values of the interfacial friction angle on contact between of the ash-slag mixture and nonwoven geotextile increased from $4 \%$ to $6 \%$, on contact with woven geotextile decreased from $2 \%$ to $3 \%$. In the case of adhesion, a decrease of its value on contact with both geoetextiles from $22 \%$ to $69 \%$ was obtained.

The test results show that the values of the friction resistance parameters on the contact of the ash-slag mixture with geotextiles are slightly smaller than the values of the shear strength parameters of the mixture itself. Similar relations are found for sandy soils, which may indicate that the mixtures may be considered as a substitute for mineral soils in some engineering applications. It can be also stated that higher values of the interaction coefficient, indicating the effectiveness of the interaction between the soil and the geotextiles, were obtained for the non-woven geotextile than for woven one.

As demonstrated, friction resistance tests in a direct shear apparatus are easy to perform and the dependence of friction resistance on normal stresses and horizontal deformations of the sample are easy to analyze. However, it should be noted that the boundary conditions connected with geosynthetics anchorage and transverse dimensions of the apparatus box may affect the results of tests on the friction resistance between the backfill and the geosynthetic. Therefore, further research on the suitability of the direct shear apparatus for determining frictional resistance will be extended to include medium-sized apparatus and the influence of geosynthetic anchorage.

Author Contributions: Conceptualization, A.G.; methodology, A.G.; software, A.G. and A.M.; validation, A.G., T.Z. and A.M.; formal analysis, A.G., T.Z. and A.M.; investigation, A.G. and A.M.; resources, A.G. and A.M.; data curation, A.G., T.Z. and A.M.; writing—original draft preparation, A.G.; writing—review and editing, A.G. and T.Z.; visualization, A.G.; supervision, A.G.; project administration, A.G.; funding acquisition, A.G. and T.Z. All authors have read and agreed to the published version of the manuscript.

Funding: This research received no external funding.

Conflicts of Interest: The authors declare no conflict of interest. 


\section{References}

1. Bergado, D.; Teerawattanasuk, C.; Wongsawanon, T.; Voottipruex, P. Interaction between Hexagonal Wire Mesh Reinforcement and Silty Sand Backfill. Geotech. Test. J. 2001, 24, 1, 23-38. [CrossRef]

2. Gruchot, A.; Świgost, T. Shear strength of the ash-slag mixture and the friction resistance at the contact surface-The mixture-geosynthetic (In Polish: Wytrzymałość na ścinanie mieszaniny popiołowo-żużlowej oraz opór tarcia na styku mieszanina-Geosyntetyk). Drogownictwo 2012, 1, 29-32.

3. Bacas, B.M.; Cañizal, J.; Konietzky, H. Shear strength behavior of geotextile/geomembrane interfaces. J. Rock Mech. Geotech. Eng. 2015, 7, 638-645. [CrossRef]

4. Jotisankasa, A.; Rurgchaisri, N. Shear strength of interfaces between unsaturated soils and composite geotextile with polyester yarn reinforcement. Geotext. Geomembr. 2018, 46, 338-353. [CrossRef]

5. Ghionna, V.N.; Mortara, G. An elastoplastic model for sand-structure interface behaviour. Geotechnique 2002, 52, 41-50. [CrossRef]

6. Punetha, P.; Mohanty, P.; Samanta, M. Microstructural investigation on mechanical behavior of soil-geosynthetic interface in direct shear test. Geotext. Geomembr. 2017, 45, 197-210. [CrossRef]

7. Palmeira, E.M. Soil-geosynthetic interaction: Modelling and analysis. Geotext. Geomembr. 2009, $27,368-390$. [CrossRef]

8. Galos, K.; Uliasz-Bocheńczyk, A. Sources and utilization of fly ashes from coal combustion in Poland (In Polish: Źródła i użytkowanie popiołów lotnych ze spalania węgli w Polsce). Gospod. Surowcami Miner. 2005, 21, 23-42.

9. Falaciński, P.; Garbulewski, K.; Kledyński, Z.; Skutnik, Z.; Ziarkowska, K. Fluidised fly-ash cement-bentonite cut-off walls in flood protection. Arch. Hydro-Eng. Environ. Mech. 2005, 52, 7-20.

10. Gruchot, A.; Zydroń, T. Geotechnical parameters of the ash-slag mixture from hard coal burning concerning its usability for earthworks (In Polish: Właściwości geotechniczne mieszaniny popiołowo-żużlowej ze spalania węgla kamiennego w aspekcie jej przydatności do celów budownictwa ziemnego). Annu. Set Environ. Prot. Rocz. Ochr. Środowiska 2013, 15, 1719-1737.

11. Gruchot, A. Utilisation of Coal Mining Wastes and Fuel Ashes for Engineering Purposes as a Factor of Environmental Development and Protection (In Polish: Utylizacja Odpadów Powęglowych i Poenergetycznych do Celów Inżynierskich Jako Czynnik Ksztattowania i Ochrony Srodowiska); Zeszyty Naukowe (Rozprawy), Uniwersytet Rolniczy im Hugona Kołłąaja: Kraków, Poland, 2016.

12. Bugajski, M.; Grabowski, W. Geosynthetics in Road Structures (In Polish: Geosyntetyki w Budownictwie Drogowym); Wydawnictwo Politechniki Poznańskiej,: Poznań, Poland, 1999.

13. Wesołowski, A.; Krzywosz, Z.; Brandyk, T. Geosynthetics in Engineering Structures (In Polish: Geosyntetyki w Konstrukcjach Inżynierskich); Wydawnictwo SGGW: Warszawa, Poland, 2000.

14. Duszyńska, A.; Sikora, Z. Geosynthetics selection for soil reinforcement (In Polish: Dobór wyrobów geosyntetycznych do zbrojenia gruntu). Inżynieria Morska Geotech. 2014, 35, 468-473.

15. Koerner, R.M. Designing with Geosynthetics, 6th ed.; Xlibris Corporation: Bloomington, IN, USA, 2012; Volume 1-2.

16. Zornberg, J.G. Functions and applications of geosynthetics in roadways. Procedia Eng. 2017, 189, $298-306$. [CrossRef]

17. Gruchot, A. Frictional resistance on the contact of ash-slag mixture and geotextile (In Polish: Opory tarcia na kontakcie mieszanina popiołowo-żużlowa a geowłóknina). Acta Sci. Pol. Form. Circumiectus 2013, 12, 55-65.

18. Duszyńska, A.; Bolt, A. Soil-Geogrid Cooperation in Pull Out Test (In Polish: Wspótpraca Georusztu i Gruntu w Badaniu na Wyciaganie); Wydawnictwo Politechniki Gdańskiej: Gdańsk, Poland, 2004.

19. Borys, M. Frictional resistance at the junction of geosynthetic anti-filtartion screens in flood embankments (In Polish: Opory tarcia na styku geosyntetycznych ekranów przeciwfiltracyjnych w wałach przeciwpowodziowych). Woda-Środowisko-Obszary Wiejskie 2007, 7, 21-31.

20. Lopes, M.L.; Ferreira, F.; Carneiro, J.R.; Vieira, C.S. Soil-geosynthetic inclined plane shear behavior: Influence of soil moisture content and geosynthetic type. Int. J. Geotech. Eng. 2014, 8, 335-342. [CrossRef]

21. Wu, W.; Wick, H.; Ferstl, F.; Aschauer, F. A tilt table device for testing geosynthetic interfaces in centrifuge. Geotext. Geomembr. 2008, 26, 31-38. [CrossRef]

22. Bergado, D.T.; Ramana, G.V.; Siaa, H.I. Evaluation of interface shear strength of composite liner system and stability analysis for a landfill lining system in Thailand. Geotext. Geomembr. 2006, 24, 371-393. [CrossRef] 
23. Basudhar, P.K. Modeling of soil-woven geotextile interface behavior from direct shear test results. Geotext. Geomembr. 2010, 28, 403-408. [CrossRef]

24. Vieira, C.S.; Lopes, M.; Caldeira, L. Sand-nonwoven geotextile interfaces shear strength by direct shear and simple shear tests. Geomech. Eng. 2015, 9, 601-618. [CrossRef]

25. Bernal, A.; Salgado, R.; Swan, R.H., Jr.; Lovell, C.W. Interaction between tire shreds, rubber-sand and geosynthetics. Geosynth. Int. 1997, 4, 623-643. [CrossRef]

26. Tang, C.; Shi, B.; Zhao, L. Interfacial shear strength of fiber reinforced soil. Geotext. Geomembr. 2010, $28,54-62$. [CrossRef]

27. Hejazi, S.M.; Sheikhzadeh, M.; Abtahi, S.M.; Zadhoush, A. A simple review of soil reinforcement by using natural and synthetic fibers. Constr. Build. Mater. 2012, 30, 100-116. [CrossRef]

28. Li, J.; Tang, C.; Wang, D.; Pei, X.; Shi, B. Effect of discrete fibre reinforcement on soil tensile strength. J. Rock Mech. Geotech. Eng. 2014, 6, 133-137. [CrossRef]

29. Gruchot, A.; Michniak, D. Compression strength of fly ash with the addition of fiber reinforcement. (in Polish: Wytrzymałość na ściskanie popiołów lotnych z dodatkiem zbrojenia rozproszonego). Acta Sci. Pol. Form. Circumiectus 2015, 14, 43-44. [CrossRef]

30. Shukla, S.K.; Sivakugan, N.; Das, B.M. A state-of-the-art review of geosynthetic-reinforced slopes. Int. J. Geotech. Eng. 2011, 5, 17-32. [CrossRef]

31. Kim, B.; Prezzi, M.; Salgado, R. Geotechnical properties of fly and bottom ash mixturesfor use in highway embankments. J. Geotech. Geoenviron. Eng. 2005, 131, 914-924. [CrossRef]

32. Zabielska-Adamska, K. Shear strength parameters of compacted fly ash-HDPE geomembrane interfaces. Geotext. Geomembr. 2006, 24, 91-102. [CrossRef]

33. Hower, J.C.; Rathbone, R.F.; Robertson, J.D.; Peterson, G.; Trimble, A.S. Petrology, mineralogy, and chemistry of magnetically-separated sized fly ash. Fuel 1999, 78, 197-203. [CrossRef]

34. Kutchko, B.G.; Kim, A.G. Fly ash characterization by SEM-EDS. Fuel 2006, 85, 2537-2544. [CrossRef]

35. Das, S.K. Characteristics and composition of magnetic concentrates of bottom ash sample from two types of thermal power plants in Odisha, India. Coal Combust. Gasif. Prod. 2016, 8, 30-43. [CrossRef]

36. Baykal, G.; Edinçliler, A.; Saygılı, A. Highway embankment construction using fly ash in cold regions. Resour. Conserv. Recycl. 2004, 42, 209-222. [CrossRef]

37. Zabielska-Adamska, K. Sewage sludge bottom ash characteristics and potential application in road embankment. Sustainability 2020, 12, 39. [CrossRef]

38. Zabielska-Adamska, K. Laboratory compaction of fly ash and fly ash with cement additions. J. Hazard. Mater. 2008, 151, 481-489. [CrossRef] [PubMed]

39. Prabakar, J.; Dendorkar, N.; Morchhale, R.K. Influence of fly ash on strength behavior of typical soils. Constr. Build. Mater. 2004, 18, 263-267. [CrossRef]

40. Dash, M.K.; Patro, S.K.; Rath, A.K. Sustainable use of industrial-waste as partial replacement of fine aggregate for preparation of concrete-A review. Int. J. Sustain. Built Environ. 2016, 5, 484-516. [CrossRef]

41. Yilmaz, Y.; Coban, H.S.; Cetin, B.; Edil, T.B. Use of standard and off-spec fly ashes for soil stabilization. J. Mater. Civ. Eng. 2019, 31, 2. [CrossRef]

42. Vukićević, M.; Marjanović, M.; Pujević, V.; Jocković, S. The alternatives to traditional materials for subsoil stabilization and embankments. Materials 2019, 12, 3018. [CrossRef]

43. Bera, A.K.; Chandra, S.N.; Ghosh, A.; Ghosh, A. Unconfined compressive strength of fly ash reinforced with jute geotextiles. Geotext. Geomembr. 2009, 27, 391-398. [CrossRef]

44. Bergado, D.T.; Youwai, S.; Teerawattanasuk, C.; Visudmedanukul, P. The interaction mechanism and behavior of hexagonal wire mesh reinforced embankment with silty sand backfill on soft clay. Comput. Geotech. 2003, 30, 517-534. [CrossRef]

45. Gruchot, A.; Zydron, T. Determination of frictional resistance at the contact between chosen furnace waste and geosynthetics. Acta Sci. Pol. Archit. 2015, 14, 35-47.

46. Giroud, J.P.; Darrasse, J.; Bachus, R.C. Hyperbolic expression for soil-geosynthetic or geosynthetic-geosynthetic interface shear strength. Geotext. Geomembr. 1993, 12, 275-286. [CrossRef]

47. Wasti, Y.; Özdügün, Z.B. Geomembrane-geotextile interface shear properties as determined by inclined board and direct shear box tests. Geotext. Geomembr. 2001, 19, 43-57. [CrossRef]

48. Hossain, B.; Hossain, Z.; Sakai, T. Interaction properties of geosynthetic with different backfill soils. Int. J. Geosci. 2012, 3, 1033-1039. [CrossRef] 
49. Bacas, B.M.; Konietzky, H.; Berini, J.C.; Sagaseta, C. A new constitutive model for textured geomembrane/geotextile interfaces. Geotext. Geomembr. 2011, 29, 137-148. [CrossRef]

50. Tanchaisawat, T.; Bergado, D.T.; Voottipruex, P.; Shehzad, K. Interaction between geogrid reinforcement and tire chip-sand lightweight backfill. Geotext. Geomembr. 2010, 28, 119-127. [CrossRef]

51. Bergado, D.T.; Chai, J.C. Pullout force/displacement relationship of extensible grid reinforcement. Geotext. Geomembr. 1994, 13, 295-316. [CrossRef]

52. Tuna, S.C.; Altun, S. Mechanical behaviour of sand-geotextile interface. Sci. Iran. 2012, 19, $1044-1051$. [CrossRef]

53. Chai, J.C.; Saito, A. Interface Shear Strengths between Geosynthetics and Clayey Soils. Int. J. Geosynth. Ground Eng. 2016, 2, 19. [CrossRef]

54. Choudhary, A.K.; Krishna, A.M. Experimental Investigation of Interface Behaviour of Different Types of Granular Soil/Geosynthetics. Int. J. Geosynth. Ground Eng. 2016, 2, 4. [CrossRef]

55. PN-EN ISO 17892-4:2017-01. Rozpoznanie i Badania Geotechniczne. Badania Laboratoryjne Gruntów. Część 4: Badanie Uziarnienia Gruntów; Polski Komitet Normalizacyjny: Warszawa, Poland, 2017.

56. PN-EN ISO 17892-3:2016-03. Rozpoznanie i Badania Geotechniczne. Badania Laboratoryjne Gruntów. Część 3: Badanie Gęestości Właściwej; Polski Komitet Normalizacyjny: Warszawa, Poland, 2016.

57. PN-EN 13286-2:2010. Mieszanki Niezwiazane i Zwiazane Hydraulicznie. Czẹść 2: Metody Badań Laboratoryjnych Gęstości na Sucho i Zawartości Wody. Zagęszczanie Metodą Proktora; Polski Komitet Normalizacyjny: Warszawa, Poland, 2010.

58. PN-EN ISO 17892-10:2019-01. Rozpoznanie i Badania Geotechniczne. Badania Laboratoryjne Gruntów. Część 10: Badania w Aparacie Bezpośredniego Ścinania; Polski Komitet Normalizacyjny: Warszawa, Poland, 2019.

59. PN-B-04481:1988. Grunty Budowlane. Badania Próbek Gruntu; Polski Komitet Normalizacji, Miar i Jakości. Wydawnictwo Normalizacyjne "Alfa": Warszawa, Poland, 1988.

60. PN-EN ISO, 14688-2:2006. Badania Geotechniczne. Oznaczanie i Klasyfikowanie Gruntów. Część 2: Zasady Klasyfikowania; Polski Komitet Normalizacyjny: Warszawa, Poland, 2006.

61. Noorzad, R.; Mirmoradi, S.H. Laboratory evaluation of the behavior of a geotextile reinforced clay. Geotext. Geomembr. 2010, 28, 386-392. [CrossRef]

62. Khoury, C.N.; Miller, G.A.; Hatami, K. Unsaturated soilegeotextile interface behavior. Geotext. Geomembr. 2011, 29, 17-28. [CrossRef]

63. Fredlund, D.G.; Morgenstern, N.R.; Widger, R.A. The shear strength of unsaturated soils. Can. Geotech. J. 1978, 15, 313-321. [CrossRef]

64. Vahedifard, F.; Mortezaei, K.; Leshchinsky, B.A.; Leshchinsky, D.; Lu, N. Role of suction stress on service state behavior of geosynthetic-reinforced soil structures. Transp. Geotech. 2016, 8, 45-56. [CrossRef]

65. Vieira, C.S.; Lopes, M.L.; Caldeira, L. Soil-geosynthetic interface shear strength by simple and direct shear tests. In Proceedings of the 18th International Conference on Soil Mechanics and Geotechnical Engineering, Paris, France, 2-6 September 2013; pp. 3497-3500.

66. Afzali-Nejad, A.; Lashkari, A.; Shourijeh, P.T. Influence of particle shape on the shear strength and dilation of sand-woven geotextile interfaces. Geotext. Geomembr. 2017, 45, 54-66. [CrossRef]

67. Lashkari, A.; Jamali, V. Global and local sand-geosynthetic interface behaviour. Géotechnique 2020, Ahead of print. [CrossRef]

(C) 2020 by the authors. Licensee MDPI, Basel, Switzerland. This article is an open access article distributed under the terms and conditions of the Creative Commons Attribution (CC BY) license (http://creativecommons.org/licenses/by/4.0/). 